\title{
The relationship between big data analytics and green supply chain management by looking at the role of environmental orientation: Evidence from emerging economy
}

\author{
Shadi Khattab ${ }^{a^{*}}$, Ishaq Al shaar ${ }^{\text {a }}$, Raed Alkaied ${ }^{a}$ and Fadi Qutaishat ${ }^{b}$
}

${ }^{a}$ Al balqa Applied University, Jordan

${ }^{b}$ Princess Sumaya University for Technology, Jordan

A B S T R A C T

Article history:

Received December 1, 2021

Received in revised format

December 15, 2021

Accepted February 32022

Available online

February 32022

Keywords:

Green supply chain management

Big data analytics

Environmental orientation
Academics and practitioners have become more interested in big data analytics (BDA) in recent years. There have been few empirical studies on the relationship between BDA and green supply chain management (GSCM), as well as the importance of environmental orientation (EO). A total of 128 responses from Jordanian industrial businesses were evaluated using the structural equation modeling method. The BDA, EO has a favorable and significant relationship with external and internal GSCM, according to the findings of this study. Furthermore, EO serves as a mediator between BDA and the external, and internal GSCM. The findings provide managerial insight into how to use BDA to establish a proactive environmental policy that covers all GSCM activities.

(C) 2022 Growing Science Ltd. All rights reserved.

\section{Introduction}

Despite supply chains' enormous success, supply chains (SCs) and their widespread proliferation in many companies (Mubarik et al., 2021). However, it has been under increasing pressure from local communities and governments to establish environmental protection rules and enforce them rigorously on businesses to avoid additional environmental damage (Song and Wang, 2018; Bag et al., 2021). Besides its detrimental influence on the natural environment at all phases of production, including the massive impact of waste from the use of natural resources, excessive environmental pollution, and waste and toxic waste treatment, resulting in environmental instabilities (Mubarik et al., 2021). As a result, environmental protection has become a primary duty of corporate owners and top management (Leonidou et al., 2015). As a result, businesses are working to develop environmentally friendly products, processes, systems, and technology (Yu \& Huo, 2019). They need to incorporate environmental management within generally known SCs (Wong et al., 2015). This prompted business to incorporate a green component into SCs, resulting in the development of a new concept known as GSCM. GSCM is a significant and practical technique for businesses to use to decrease pollution (Zhang et al., 2021). Companies can engage in green practices in more active and effective ways that contribute to the formation of an EO culture among suppliers, and therefore achieve higher performance (Chan et al., 2012; Zhou et al., 2008). Many environmental issues are caused by SC partners' operations rather than its operations (Lai et al., 2013). The extent to which a firm is concerned about and participates in reversing environmental degradation (Fraj-Andr es et al., 2009; Banerjee, 2002) is a critical component of environmental protection. EO refers to a company's level of environmental responsibility and the necessity to mitigate its impact; it also refers to the many steps taken by the firm to decrease the harm and environmental impact of its everyday operations (Yu and Huo, 2019). Companies are focusing on EO to meet the environmental expectations of internal and external stakeholders including regulatory authorities, employees, customers, members of the community, and suppliers (Yasir et al., 2020). The internal EO, according to Banerjee et al., (2003), will enable the company's members to create a collective understanding of the need of adopting environmentally friendly processes, and will ultimately inspire them to look for ways to lessen the environmental consequences of these operations. GSCM is a new discipline that aims to address some of the SC's typical flaws, such as environmental efficiency (Chin et al., 2015). Consequently, to become even more environmentally friendly, organizations are incorporating GSCM with other business management tasks such as manufacturing, purchasing, and * Corresponding author

E-mail address: shadikhattab@bau.edu.jo (S. Khattab)

(C) 2022 Growing Science Ltd. All rights reserved.

doi: $10.5267 /$ j.uscm.2022.2.002 
maintenance, as well as logistics (Song et al., 2018; Tseng et al., 2018). SC effectiveness is influenced by information exchange and collaborative efforts, both of which are important aspects (Gunasekaran et al., 2017). As a result, information management aids in the facilitation of logistic flow, which is a vital success component in a turbulent corporate environment. Sharing information with suppliers, customers, and SC partners can help you save money while also improving your environmental performance (Zhang and Yang, 2016). Green processes and practices, as well as a company's environmental and economic success, rely heavily on IT (Khan et al., 2016).

Over the last few years, research on the importance of big data in SCM has rapidly increased, with a particular focus on applications in manufacturing, procurement, and logistics (Brinch, 2018). As a result, the concept of big data in SCM is still nascent, the underlying theories in this subject are diverse, and researchers in this field require sound assumptions about our existing knowledge to undertake rigorous research (Frizzo-Barker et al., 2016). We must increase our grasp of big data, and organizations must be guided on how to make the most of the huge volumes of data available (George et al., 2014). In this context, the employment of Artificial Intelligence (AI) results in a problem-solution that is more accurate, faster, and requires less input (Huin et al., 2003; Toorajipour et al., 2021). However, in recent times technological developments have shown that AI has a wide range of applications in various processes in many areas, such as SCM (Min, 2010; Jarrahi, 2018). Many AIbased functional SC applications, including machine learning, natural language processing, and robotics, have arisen in recent years (Riahi et al. 2021). AI enables systems to make wise decisions and perform tasks automatically without human intervention. Companies are exploiting AI and machine learning to gain insights into different areas, including warehousing, logistics, and SCM (Riahi et al. 2021). Jeble et al. (2018) pointed out that the relationship between BDA and sustainable SC performance is interesting and needs more studies in the future. Many studies have addressed the role of BDA in SCs (Nguyen et al., 2021; Belhadi et al. 2020; Kamble \& Gunasekaran, 2020; Jha et al., 2020; Roßmann et al., 2018; Tiwariet al., 2018; Yu et al., 2021; Brinch, 2018; Mandal, 2018; Queiroz \& Telles, 2018; Mandal, 2019; Fernando et al., 2018; Toorajipour et al., 2021; Riahi et al., 2021). Few studies looked at BDA's function in GSCM (Benzidia et al., 2021), green purchasing (AlNuaimi et al., 2021), and sustainable SCs (Chalmeta and Barqueros-Muoz, 2021; Hazen et al., 2016; Bag et al., 2020; Shokouhyar et al., 2020; Jeble et al.). SC conceptual and empirical investigations, according to Eckstein et al. (2015), have disregarded the influence of crucial contextual elements. Moreover, Chen et al. (2015) and Wamba et al., 2020 stated that empirical studies on the ability of BDA have largely ignored the impact of environmental dynamics. Based on the above, GSCM and BDA in light of different degrees of environmental trends remain a clear research gap that needs further study and analysis. Therefore, the current study attempts to investigate the relationship between BDA and GSCM in light of the company's environmental orientations.

\section{Big data analytics}

Many academics have recently become interested in BDA because of its analytical capabilities, which have led to the extraction of vast volumes of data and important information in a variety of economic industries (Bilal et al., 2016; Shokouhyar et al., 2020). In addition to its ability to use techniques that help retrieve valuable insights from the flow of information, enabling company managers to make more informed decisions based on data rather than human opinion or intuition (Benzidia et al., 2021; Arunachalam et al., 2018), especially in SCM (Benzidia et al., 2021), it also has the ability to use techniques that help extract valuable insights from the flow of information (Wamba et al., 2015). Where decisionmaking is an essential and vital component of effective and successful management (Roßmann et al., 2018). To do so, the extra data must first be translated into decisions that provide value to customers or improve operations to gain sustainable competitive advantage (Tan et al., 2015). In addition, the amount of data produced and accessible to organizations is always increasing (Arunachalam et al., 2018; Kache \& Seuring, 2017). The importance of BDA in the decision-making process has grown because of rapid technological advancement (Chen et al., 2012). This necessitates the fine-tuning of certain technologies to cope with potentially massive data sets and, as a result, spot trends, establish patterns, and collect useful information (Zhong et al., 2017). Technological advancements have resulted in a growth in the volume of data, allowing users to take advantage of the benefits of technology integration to gain useful information (Pan et al., 2017; Ramanathan et al., 2017). This information necessitates the development of cutting-edge technology infrastructures designed to perform precise and scalable big data analysis (Priya and Kumar, 2015). Along with the increasing volume, data has also become more diverse, because of the multiplicity of new data sources. Thus, more advanced measures are needed to integrate unstructured and heterogeneous data formats to improve SC performance (Zhong et al., 2016; Fernando et al., 2018), including textual structures from social media or location-sensing data, temperature, and humidity (Li \& Wang, 2017).

\section{Environmental orientation}

Standard economic growth is dependent on resource use, which has unintended negative environmental repercussions because of resource usage and pollution creation (Hall et al., 2010). Environmental development is in line with efforts to reduce adverse environmental impact, built on the indisputable conclusion that conventional economic growth is linked to resource usage, implying negative environmental implications of resource consumption and pollution production (Chavez et al., 2021). Several challenges have arisen because of climate change and environmental harm, necessitating environmentally conscious behavior (Gavronski et al., 2011). Companies are increasingly being pressured by society and stakeholders to adopt environmentally friendly policies (Chan et al., 2012; Mubarik et al., 2021). Businesses' worries have grown because of these restrictions, forcing them to include pro-environmental components into their production, sales, and other operations (Green et al., 2012). The corporate idea of environmental preservation, which is frequently adopted as part of CSR or even branding 
campaigns in major firms, exemplifies environmental consciousness (Chavez et al., 2021). Companies must recognize environmental difficulties and associated environmental considerations must be proactively integrated into business strategy, according to EO (Banerjee, 2002). Companies may engage in environmentally friendly operations to maintain a balance in economic and environmental performance, given the importance of the foregoing challenges (Bu et al., 2020), higher-level management recognizes that a company's operations, such as product creation, sourcing, manufacturing, and distribution, may cause environmental difficulties (Banerjee, 2002). There is scientific proof that EO improves company performance, and businesses must understand the value of environmental actions. Keszey (2020), for example, looked into the relationship between $\mathrm{EO}$ and firm performance.

\section{Relation between BDA and Environmental orientation, green supply chain management}

The use of BDA in SCM has been mentioned by Waller and Fawcett (2013). It has been obvious the importance of applying advanced BDA related to SC activities on several domains such as SC design, competitiveness, predictive analytics, business analytics, BDA, and SC analytics (Schoenherr and Speier-Pero, 2015). As well as to improve the resilience of SC networks (Papadopoulos et al., 2017), reduce costs, and improve environmental efficiency (Chen and Jia, 2017). According to several pieces of research, BDA has a positive impact on helping companies achieve social and economic goals while lowering environmental problems (Raut et al., 2021). As a result, BDA is an important instrument in SCM and will help to construct future sustainable SCs (Chalmeta \& Barqueros-Muoz, 2021). Through customer integration, supplier integration, and process design, BDA has the potential to significantly transform SC performance (Gunasekaran et al., 2017; Raut et al., 2021). The creation of distribution networks is one of the fundamental difficulties in SCM. Wang et al. (2018) developed a model that uses massive amounts of data generated by distribution centers to identify the best number of distribution centers in relation to client needs. Inventory management is another crucial decision in SCM. In this case, Choi (2018) presented a model for determining the impact of social media feedback in a big data environment on retailer inventory decisions. BDA can help improve the functions of purchasing and warehousing, manufacturing and production planning, quality control, and logistics management (Govindan et al., 2018). The BDA method has been used to forecast the performance of online markets (Li et al., 2016). BDA can also be utilized for smart manufacturing and complex product manufacturing (Zhang et al., 2017; Zhong et al., 2017). Kumar et al. (2016) proposed leveraging the MapReduce framework to apply BDA for fault diagnosis in cloud manufacturing. Intelligent Transportation Systems based on BDA for traffic flow prediction and intelligent transportation were the focus of Li et al. (2015) and Wang et al. (2016). Zhao et al. (2017) presented a BDA-based paradigm for greening SCs. BDA contributes to the long-term viability of SC by boosting capacities and lowering risk and uncertainty (Wu et al., 2017; Raut et al., 2021). According to Joghee et al. (2021), business intelligence systems, internal greening, and external greening have a favorable impact on organizations' green performance, which helps them improve their positions. The results of Mubarik et al. (2021) emphasized the positive impact of blockchain on green SC practices. According to the findings of the Shokouhyar et al. (2020) study, BDA has a significant impact on SC sustainability. BDA for management competencies has a significant and influential impact on both green product development and sustainable SC results, according to Bag et al. (2020). BDA could be used to test certain designs in the context of resilient SCs that promote sustainability, according to Papadopoulos et al. (2017). Several authors (Kamble \& Gunasekaran, 2020; Belhadi et al. 2020; Edwin Cheng et al., 2021) emphasize the role of BDA in providing insights into internal and external SC integration activities. Evidence has been found for the role of BDA to simplify SC operations and contribute to the development of a sustainable system (Belhadi et al. 2020; Mangla et al. 2020). Mageto (2021) and Jeble et al. (2018) found that BDA enhances the sustainability of SCs and this leads us to the following assumptions:

H1. There is a positive relationship between BDA and external GSCM.

$\mathbf{H}_{2}$. There is a positive relationship between BDA and internal GSCM.

H3. There is a positive relationship between BDA and environmental orientation.

\section{The mediating role of EO}

Valuable, rare, and difficult-to-copy resources, according to the RBV, can help businesses achieve sustainability and obtain competitive advantages (Yu and Huo, 2019). Furthermore, arranging resources enables businesses to make the most of their core resources and successfully develop key capabilities (Zhou et al., 2008). As a result, an environmentally conscious organization can improve the implementation of GSCM by utilizing appropriate resources. Internal and external environmental trends, according to Chan et al. (2012), are a vital prerequisite for creating environmental protection and safety plans. Management attitudes associated with EO, environmental innovation, and the strategic direction of environmental reputation, according to empirical evidence, encourage green resource management (Kirchoff et al., 2016). Chan and Ma (2021) see both the internal and external environmental trends of international buyers acting as a major driver for their green supplier development. Internal environmental trends can help companies build a common understanding of the importance of environmentally sustainable practices, and thus encourage them to try to find alternatives to reduce the environmental impacts of these activities (Chan et al., 2012). The external EO of stakeholders motivates companies to improve interior design, production processes, and gradually replace traditional technologies with green technologies to reduce environmental impact (Dong et al., 2021). Furthermore, it may compel companies to extend their environmental management to suppliers (Krause et al., 2009), and require suppliers to consider environmental dimensions. Hence, the managerial interpretation implies that the external EO will have a positive impact on GSCM (Fraj-Andrés et al., 2009). Sustainable orientation, according to Beske (2012), is one of the primary components supporting the SC's long-term viability. According to Silva and 
Alves (2019), a company's commitment to sustainability is a key component in the development of sustainable supply chain management. Studies by Namagembe et al. (2016) and Habib et al. (2021) showed that EO positively affects the adoption of green SC practices. The study of Chan et al. (2012) revealed that internal and external environmental trends have a positive and important impact on the practice of green purchasing and customer cooperation. Similarly, Yu and Huo (2019) significantly noted the positive impact of the environmental trend on managing green supply sources. External EO, according to Peng and Wei (2015) and Yasir et al. (2020), provides the principles on which firms engage in adjusting their green strategies to better suit the demands of external stakeholders. EO trends can be inferred, push organizations to build GSCM. As a result, we can make the following assumptions:

H4. EO mediates the relationship between BDA and external GSCM.
H5. EO mediates the relationship between BDA and internal GSCM.

\section{Research methodology}

This study aimed to explorer the mediating effect of EO on the relationship between BDA and GSC. We built a theoretical framework and statistically evaluated it using a survey of industrial enterprises to study the link between the factors. According to Hair et al. (2011) we employed structural equation modeling to evaluate the hypothesis, and we used a twostep technique.

\subsection{Measures}

The validity and reliability of measurement items were used to evaluate the measuring model. Based on theories, we developed a questionnaire that addressed each of the researched dimensions. Previous research was used to develop the survey questionnaire items. To evaluate the constructs, we used a five-point Likert scale with anchors that ranged from "strongly disagree" to "strongly agree". This research employed three primary constructs:

Big data analytical: According (Srinivasan and Swink, 2018; Dubey et al., 2019; Benzidia et al., 2021; Yu et al., 2021; Fernando et al., 2018; Agarwal and Weill, 2012). Sophisticated analytics approaches (e.g., simulation, optimization, and regression) are being used to aid decision-makers in comprehending massive data, multiple sources of data are used, information visualization methods (e.g., dashboards) are used to aid decision-makers in capturing big data, GSC process dashboard apps deployment on communications technology (e.g., smartphones, laptops), and BDA was measured using seven items to examine massive data sets.

External GSCM: Adapted from (Singh \& El-Kassar, 2019; Benzidia et al., 2021; Gunasekaran et al.,2017; Bag et al., 2020). External GSCM was measured using eight items including; suppliers are chosen based on the company's environmental objectives, suppliers are advised on environmental technical difficulties, Suppliers are engaged in the eco-design and development of products, supplier plants/sites are subjected to environmental audits, our company works with suppliers and customers to develop environmentally friendly goods, our core supply chain is capable of delivering complete orders on time to our end clients, and our business ensures that products purchased do not include environmentally damaging elements such as lead or other poisonous toxins.

Internal GSCM: Adapted from (Zhu et al., 2013; Laosirihongthong et al., 2013; Abdullah et al., 2015; Zaid et al., 2018). Internal GSCM was measured using six items Including; GSCM's top management is devoted to environmental stewardship, ensuring that the packaging for the products is reusable, product development that reduces the number of materials or energy utilized, designing goods that allow for material reuse, recycling, and recovery, reporting on the environment for internal evaluation, and product design that avoids or reduces the use of hazardous substances.

Environmental orientation: According to (Chavez et al., 2021; Mariadoss et al., 2016; Chan et al., 2012; Yu and Huo, 2019), EO was measured using six items including environmental preservation is important to our employees, we have clear policy statements encouraging environmental awareness, and environmental preservation developments in the natural environment have an impact on our company's business activities.

\subsection{Survey design}

To collect data from Jordanian SCM experts, the study used a quantitative technique based on a web-based survey. Jordan was chosen because, in recent years, Jordan has worked to improve the economy's sustainability and create a green economy. Where the green economy received attention at the level of the Hashemite leadership, as His Majesty King Abdullah and the Crown Prince participated in many conferences and seminars that focused on the green economy, and the Jordanian government launched the national plan for green growth in 2016, which specifically aims to establish urgent projects to sustain resources (http http://www.moenv.gov.jo/). The European Bank for Reconstruction and Development and the European Union also launched the first comprehensive internationally supported program for the green economy in the Kingdom (EBRD and the European Union Report, 2021). Jordan incorporates sound environmental principles into its procurement policies and collaborates with several international partners to set and comply with standards and guidelines, including the UNEP Sustainable Public Procurement Program. 


\subsection{Sampling and data collection}

To meet the study's aims, a sufficient sample of the targeted study population was required, who are the workers in SCM functions in industrial companies in Jordan. This research focused on firms who have already integrated business intelligence into their SC function. We found 29 organizations in Jordan that apply BDA strategies in supply chain management after conducting an initial survey. We subsequently sent invites to these companies through email, along with a description of the study's goal. Only 19 companies responded to this email and we sent a message to their entity's point of contact. After reaching each of these places, we discovered that approximately 230 employees are working in SCs within these companies, which is the study's aim. After gaining permission from each company, the questionnaire was emailed to $230 \mathrm{SC}$ experts working in Jordanian organizations via the Survey Monkey software platform. A total of 160 persons participated in the survey, with a response rate of 69.5 percent. To be more precise, the findings were not accepted until the respondents' work in the SC function was verified, which resulted in 32 responses being eliminated, resulting in a final sample size of 128 , with a response rate of 55.6 percent.

Table 1

Analysis of validity and reliability

\begin{tabular}{|c|c|c|c|c|}
\hline Items & Factor loading & $\mathrm{CR}$ & AVE & $\alpha$ \\
\hline \multicolumn{5}{|l|}{$B D A$} \\
\hline BDA1 & 0.843 & \multirow[t]{7}{*}{0.938} & \multirow[t]{7}{*}{0.716} & \multirow[t]{7}{*}{0.938} \\
\hline BDA2 & 0.797 & & & \\
\hline BDA3 & 0.873 & & & \\
\hline BDA4 & 0.808 & & & \\
\hline BDA5 & 0.860 & & & \\
\hline BDA6 & 0.871 & & & \\
\hline BDA7 & 0.839 & & & \\
\hline \multicolumn{5}{|c|}{ External GSCM } \\
\hline EGSCM1 & 0.860 & \multirow[t]{8}{*}{0.950} & \multirow[t]{8}{*}{0.726} & \multirow[t]{8}{*}{0.949} \\
\hline EGSCM2 & 0.871 & & & \\
\hline EGSCM3 & 0836 & & & \\
\hline EGSCM4 & 0.852 & & & \\
\hline EGSCM5 & 0.844 & & & \\
\hline EGSCM6 & 0.849 & & & \\
\hline EGSCM7 & 0.861 & & & \\
\hline EGSCM8 & 0.841 & & & \\
\hline \multicolumn{5}{|c|}{ Internal GSCM } \\
\hline IGSCM1 & 0.873 & \multirow[t]{6}{*}{0.973} & \multirow[t]{6}{*}{0.756} & \multirow[t]{6}{*}{0.966} \\
\hline IGSCM2 & 0.898 & & & \\
\hline IGSCM3 & 0.895 & & & \\
\hline IGSCM4 & 0.862 & & & \\
\hline IGSCM5 & 0.814 & & & \\
\hline IGSCM6 & 0.845 & & & \\
\hline \multicolumn{5}{|l|}{ EO } \\
\hline EO1 & 0.817 & \multirow[t]{6}{*}{0.912} & \multirow[t]{6}{*}{0.693} & \multirow[t]{6}{*}{0.912} \\
\hline $\mathrm{EO} 2$ & 0.818 & & & \\
\hline EO3 & 0.843 & & & \\
\hline EO4 & 0.852 & & & \\
\hline EO5 & 0.812 & & & \\
\hline EO6 & 0.813 & & & \\
\hline
\end{tabular}

Table 2

Overall fit indices

\begin{tabular}{lcc}
\hline Fit indices & Standard & Results \\
\hline$\chi 2 /$ df & $<3$ & 1.794 \\
RMSEA & $<0.1$ & 0.062 \\
RMR & $<0.05$ & 0.044 \\
NFI & $>0.9$ & 0.948 \\
AGFI & $>0.8$ & 0.822 \\
GFI & $>0.8$ & 0.896 \\
CFI & $>0.9$ & 0.971 \\
\hline
\end{tabular}

\subsection{Reliability and validity analysis}

To evaluate the study hypotheses, we utilized two methods: first, we calculated the confirmatory factor analysis (CFA) to determine convergent and discriminant validity, and then we applied structural equation modeling (SEM) with Amos 18 to test the assumptions. In the CFA model, each item was linked to its corresponding construct, and covariances between the constructs were flexibly estimated. The measurement model fit was assessed using common model-fit measures, based on the findings (as shown in Table 2): $\chi 2$ /df = 1.794; GFI =0.896; AGFI =0.822; RMSEA $=0.062 ; \mathrm{CFI}=0.971 ; \mathrm{NFI}=0.948$; $\mathrm{RMR}=0.044$ (Hair et al., 2011). 
The CFA results for the overall measurement model approve convergent validity. Thus, this study found that all items' factor loadings were acceptable and statistically significant, and greater than value 0.5, as shown in Table (1). Factor loadings were found to be more than 0.50 in the range $(0.797-0.871)$. Furthermore, the scale composite reliability is significantly higher than the prescribed value of 0.70 . As a result, the extracted average variance (AVE) constructs ranged from (0.693-0.726), which is more than 0.5 . As a result of these tests, convergent validity is supported by the data (Fornell \& Larcker, 1981; Hair et al., 2011). The square root of the AVE for each construct is more than the total inter-correlation of constructs, as shown in Table (3), showing that discriminant validity is sufficient (Fornell and Larcker, 1981). According to Nunnally (1994) and Kock (2014), a Cronbach's value greater than 0.7 indicates good reliability. As indicated in Table 1, all of Cronbach's values are above the threshold value of 0.70 . As a result, the internal consistency that had been suspected was proven.

Table 3

Inter-correlation of constructs

\begin{tabular}{|c|c|c|c|c|}
\hline Variable & 1 & 2 & 3 & 4 \\
\hline$B D A$ & 0.939 & & & \\
\hline$E O$ & $0.247 * * *$ & 0.966 & & \\
\hline External GSCM & $0.274 * * *$ & $0.634 * * *$ & 0.971 & \\
\hline Internal GSCM & $0.217 * * *$ & $0.573 * * *$ & $0.767 * * *$ & 0.964 \\
\hline
\end{tabular}

The diagonal (bold) numbers are the square root of the AVE

$* *$ Sig $<.0 .05 ; * *$ Sig $<.0 .01$

Table 4

Correlation coefficients

\begin{tabular}{lccc}
\hline Variable & 1 & 2 & 3 \\
\hline$B D A$ & $\mathbf{1}$ & & \\
$E O$ & $0.462^{* * *}$ & $\mathbf{1}$ & \\
External GSCM & $0.505^{* * *}$ & $0.727^{* * *}$ & $\mathbf{1}$ \\
Internal GSCM & $0.406^{* * *}$ & $0.662^{* * *}$ & $0.713^{* * *}$ \\
\hline
\end{tabular}

The diagonal (bold) numbers are the square root of the AVE

$* *$ Sig $<.0 .05 ; * * *$ Sig $<.0 .01$

\subsection{Testing of hypotheses}

To evaluate the hypotheses, we employed structural equation modeling (AMOS software). The results of the study hypotheses testing (Table 5) show that BDA has a significant, positive relationship with external GSCM with a p-value of $<0.01(\beta=$ $0.271, \mathrm{t}=3.874)$, and BDA has a significant, positive relationship with internal GSCM with a $p$-value of $<0.05(\beta=0.137$, $\mathrm{t}=2.001)$, confirming H1 and H2. BDA and EO have a positive relationship, with a $\mathrm{p}$-value of $<0.01(\beta=0.554$, $\mathrm{t}=6.425)$, and EO has a positive relationship with external GSCM, with a p-value of $<0.01(\beta=0.612, t=7.120)$; hence, H3 and H4 are confirmed. H5 is confirmed because there is a positive relationship between EO and internal GSCM with a p-value of $<$ $0.01(\beta=0.619, \mathrm{t}=8.496)$.

\section{Table 5}

The results of path analysis

\begin{tabular}{|c|c|c|}
\hline Path & Estimate & t-value \\
\hline $\mathrm{BDA} \rightarrow$ Externa lGSCM & 0.271 & $3.874 * * *$ \\
\hline $\mathrm{BDA} \rightarrow$ Internal GSCMt & 0.137 & $2.001 * *$ \\
\hline $\mathrm{BDA} \rightarrow \mathrm{EO}$ & 0.554 & $6.425 * * *$ \\
\hline $\mathrm{EO} \rightarrow$ External GSCM & 0.612 & $7.120 * * *$ \\
\hline $\mathrm{EO} \rightarrow$ Internal GSCM & 0.619 & $8.496 * * *$ \\
\hline
\end{tabular}

Notes: $* * p<0.05 ; * * p<0.01$

\subsection{The Mediating Effect Analysis}

According to Baron and Kenny (1986), the independent variable should have a considerable impact on the dependent variable in order to identify a mediating effect.; the independent variable should have a significant effect on the mediating variable; the mediating variable must have a significant effect on the dependent variable, and the mediation variable must decrease (partial mediation) or remove (total mediation) the independent variable's effect on the dependent variable. After the four prerequisites have been accomplished, full mediation can begin. Once the first three criteria are met, partial mediation could be accomplished. Table (6) depicts the four conditions given by Baron and Kenny for the path from BDA to external GSCM, namely, the path coefficient is $(0.215)$ and the t-value is $(4.140, p<0.01)$. External GSCM is influenced by environmental orientation (EO) with a coefficient of (0.628) and a t-value of (12.109). These findings suggest that EO acts as a link between BDA and external GSCM. The path from BDA to internal GSCM is depicted in Table 7, with a coefficient of (0.126) and a $\mathrm{t}$-value of $(2.152, \mathrm{p}<0.01)$. The EO, which has a path coefficient of $(0.604)$ and a t-value of $(10.347, \mathrm{p}<0.01)$, has an impact on internal GSCM. As a result, EO acts as a mediator for BDA and internal GSCM. 
Table 6

The results of the mediating effect of EO on BDA and External GSCM

\begin{tabular}{|c|c|c|c|c|}
\hline \multirow[t]{2}{*}{ Research construct } & \multicolumn{3}{|c|}{ External GSCM } & \multirow{2}{*}{$\begin{array}{c}\text { EO } \\
\text { Mode } 2(x \ldots z)\end{array}$} \\
\hline & Mode 1(x...z) & Mode 3(x...z) & Mode $4(x+y \ldots z)$ & \\
\hline BDA & $0.505 * * *$ & & $0.215 * * *$ & $0.462 * * *$ \\
\hline EO & & $0.727 * * *$ & $0.628 * * *$ & \\
\hline
\end{tabular}

Table 7

The results of the mediating effect of EO on BDA and internal GSCM

\begin{tabular}{|c|c|c|c|c|}
\hline \multirow[t]{2}{*}{ Research construct } & \multicolumn{3}{|c|}{ Internal GSCM } & \multirow{2}{*}{$\begin{array}{c}\text { EO } \\
\text { Mode } 2(x \ldots z)\end{array}$} \\
\hline & Mode 1(x...z) & Mode 3(x...z) & Mode $4(x+y \ldots z)$ & \\
\hline BDA & $0.406^{* * *}$ & & $0.126^{* *}$ & $0.462 * * *$ \\
\hline EO & & $0.662 * * *$ & $0.604 * * *$ & \\
\hline
\end{tabular}

\section{Discussion}

Our findings revealed that BDA has a positive effect on GSGM. These findings back with claims made in several recent conceptual and empirical research that using BDA strategies improves SC stakeholder cooperation. Hundreds of business processes are considered in the GSC. The GSCM system is a highly dynamic and complicated system in which each activity is linked to other processes to complete a task. As a result, AI may be used to plan and control GSCM systems (Bag et al., 2020). An AI-based technology enablement is a valuable tool for building the relationship between the green customer, the green supplier, and business partners in the GSC through the exchange of information across SC activities. AI systems add significant value to SC coordination and collaborative demand planning in the GSC (Min, 2010). Given that BDA offers high-level skills for timely decision-making, AI systems were able to address many GSCM analytical issues that existing models failed to answer through cooperation to gather and analyze a significant quantity of data with great quality for decision-making. Previous researchers (Singh and Teng, 2016) claimed that IT is an indispensable resource to help implement GSCM practices. The results of this study are consistent with the results of studies (Hazen et al., 2014; Dubey et al., 2019; Benzidia et al., 2021; Shokouhyar et al., 2020; Jeble et al., 2018; Mageto, 2021; Mubarik et al.., 2021; Joghee et al., 2021; Papadopoulos et al., 2017). Our findings are also consistent with recent research (Lamba et al., 2019) released in Engineering and Technology, which proved the importance of BDA in the evaluation and selection of candidates. For industrial firms that work in a dynamic and unpredictable environment, this is a huge benefit to BDA. The results showed that there is an impact of the EO on the management of the GSC, this indicates a significantly positive impact of the EO on the management of green resources, which indicates that the EO facilitates the management of green resources. Resources that are difficult to duplicate, precious, and rare, according to RBV, can help businesses attain competitive sustainability advantages. Furthermore, structuring resources enables businesses to make the most of vital resources and successfully develop core capabilities (Kirchoff et al., 2016). As a result, an environmentally conscious organization can improve the implementation of GSCM by utilizing appropriate resources. Management's approach to the natural environment, as well as EO, can improve green resource management, according to empirical evidence. This result is consistent with research findings of (Chan et al., 2012; Zhou et al., 2008; Yu and Huo, 2019; Silva and Alves, 2019; Namagembe et al., 2016; Habib et al., 2021). Environmentally conscious businesses are more responsive to stakeholder demands and challenges, which may lead to environmental protection policies in SCs such as green supplier management. This is in line with Dai et al. (2015), who predict that large competitors' success in managing the environmental initiatives will motivate businesses to make measures that will aid in the integration of the GSC.

According to the findings, green technology learning helps companies improve their management orientation against successful integration of the environmental approach in structure, transportation, and supply operations, which is very beneficial in boosting an interactive environmental strategy among company managers and SC partners. This research brings up the topic of using environmental learning technology in the workplace, particularly in industrial settings. This shows that corporate practices and strategies can be effectively integrated with environmental culture. This outcome is in line with research findings of (Benzidia et al., 2021; Mubarik et al., 2021).

According to the findings, the EO mediates the effect of BDA on GSGM. This supports the findings of (Oláh et al., 2020; Liu and De Giovanni, 2019; Mubarik et al., 2021; Wamba et al., 2020) that Business Intelligence reduces waste and encourages environmental protection behavior, resulting in improved GSC practices such as green building, green purchasing, green manufacturing, and green distribution.

Moreover, the researchers claim that EO of businesses is needed to incorporate sustainability methods, preservation, and greening through manufacturing technologies such as BDA; by instilling the technical aspects in businesses and inspiring them to use BDA to make a contribution to pro-environmental business activities, by eradicating processes, environmentally damaging goods, models, and supply chains. 


\section{Managerial implications}

The findings of this research can help managers adopt and apply GSCM methods. Businesses should develop a strong environmental orientation since EO, or pro-environmental conduct can significantly speed up integration across GSC pathways by reducing unnecessary paperwork. An environmentally conscious business might take on greater environmental protection and green management obligations. As a result, the business's green and brand image increases, yielding significant financial benefits. To strengthen GSCM, businesses should increase environmental training and education, establish an environmental management system, and raise environmental consciousness among all workers through improved incentive and punishment systems. Implementing GSCM principles can save the firm money. For example, if a company allows for real-time forecasting of demand and supply, it can decrease unnecessary production and enable enterprises to adopt production promptly, saving a variety of expenditures. Increasing environmental and social consciousness is becoming increasingly vital as the supply of green products and services is now a critical part of the performance of the company. Green products may improve consumer satisfaction, boost product sales, and help a business make more money. Green activism must be promoted both internally and externally by businesses. Decision-makers in the BDA have the potential to use their current technical capabilities to establish a proactive environmental strategy that covers all GSCM activities. Managers can use BDA technology, for example, to apply new metrics and indices in real-time in order to better grasp and absorb facts regarding environmental durability, which supports the green economy concept.

\section{Limitation and future research}

There are various limitations to this study

First, this research relied on a relatively small sample of 128 respondents, which was taken from industrial companies that use BDA in Jordan due to the limited companies that use this technology. Future research can reach a larger sample or apply the study to other sectors and make a comparison between them, or employ a case study.

Second, this study focuses solely on the technological component based on (BDA); however, other technological aspects may be examined in future research. Future research should look into the importance of green intellectual capital, data-driven culture, and organizational learning in modifying the impact of BDA in GSCM, as well as studies on BDA's impact on SC coordination and integration. An inquiry into the use of BDA in SC risk management could be part of future research.

Third, the data for this study was only gathered in one country. Future research could include more countries with a variety of cultural backgrounds and cultural influences.

\section{References}

Abdullah, M., \& Thurasamy, R. (2015). An exploratory study of GSCM practices and supply chain integration among Malaysia manufacturing firms. Australian Journal of Basic Applied Science, 9(37), 50-56.

Agarwal, R., \& Weill, P. (2012). The benefits of combining data with empathy. MIT Sloan Management Review, 54(1), 135.

AlNuaimi, B. K., Khan, M., \& Ajmal, M. M. (2021). The role of big data analytics capabilities in greening e-procurement: A higher order PLS-SEM analysis. Technological Forecasting and Social Change, 169, 1-13.

Arunachalam, D., Kumar, N., \& Kawalek, J. P. (2018). Understanding big data analytics capabilities in supply chain management: Unravelling the issues, challenges and implications for practice. Transportation Research Part E: Logistics and Transportation Review, 114, 416-436.

Bag, S., Wood, L. C., Xu, L., Dhamija, P., \& Kayikci, Y. (2020). Big data analytics as an operational excellence approach to enhance sustainable supply chain performance. Resources, Conservation and Recycling, 153, 1-10.

Banerjee, S. B. (2002). Corporate environmentalism: The construct and its measurement. Journal of business research, 55(3), 177-191.

Banerjee, S. B., Iyer, E. S., \& Kashyap, R. K. (2003). Corporate environmentalism: Antecedents and influence of industry type. Journal of marketing, 67(2), 106-122.

Baron, R. M., \& Kenny, D. A. (1986). The moderator-mediator variable distinction in social psychological research: Conceptual, strategic, and statistical considerations. Journal of personality and social psychology, 51(6), 1173.

Belhadi, A., Kamble, S. S., Zkik, K., Cherrafi, A., \& Touriki, F. E. (2020). The integrated effect of Big Data Analytics, Lean Six Sigma and Green Manufacturing on the environmental performance of manufacturing companies: The case of North Africa. Journal of Cleaner Production, 252, 119903.

Benzidia, S., Makaoui, N., \& Bentahar, O. (2021). The impact of big data analytics and artificial intelligence on green supply chain process integration and hospital environmental performance. Technological Forecasting and Social Change, 165 , $1-13$.

Beske, P. (2012). Dynamic capabilities and sustainable supply chain management. International Journal of Physical Distribution \& Logistics Management, 42(4), 372-387. 
Bilal, M., Oyedele, L. O., Qadir, J., Munir, K., Ajayi, S. O., Akinade, O. O., ... \& Pasha, M. (2016). Big data in the construction industry: A review of present status, opportunities, and future trends. Advanced engineering informatics, 30(3), 500-521.

Brinch, M. (2018). Understanding the value of big data in supply chain management and its business processes: Towards a conceptual framework. International Journal of Operations \& Production Management, 38(7), 1589-1614.

Bu, X., Dang, W. V., Wang, J., \& Liu, Q. (2020). Environmental orientation, green supply chain management, and firm performance: Empirical evidence from Chinese small and medium-sized enterprises. International journal of environmental research and public health, 17(4), 2-17.

Chalmeta, R., \& Barqueros-Muñoz, J. E. (2021). Using big data for sustainability in supply chain management. Sustainability, 13(13), 1-25.

Chan, R. Y., \& Ma, K. H. (2021). How and when environmental orientation drives corporate sustainable development in a cross-national buyer-supplier dyad. Business Strategy and the Environment, 30(1), 109-121.

Chan, R. Y., He, H., Chan, H. K., \& Wang, W. Y. (2012). Environmental orientation and corporate performance: The mediation mechanism of green supply chain management and moderating effect of competitive intensity. Industrial Marketing Management, 41(4), 621-630.

Chavez, R., Malik, M., Ghaderi, H., \& Yu, W. (2021). Environmental orientation, external environmental information exchange and environmental performance: Examining mediation and moderation effects. International Journal of Production Economics, 240, 108222.

Chen, D. Q., Preston, D. S., \& Swink, M. (2015). How the use of big data analytics affects value creation in supply chain management? Journal of Management Information Systems, 32(4), 4-39.

Chen, H., Chiang, R. H., \& Storey, V. C. (2012). Business intelligence and analytics: From big data to big impact. MIS quarterly, 36(4), 1165-1188.

Chen, L., \& Jia, G. (2017). Environmental efficiency analysis of China's regional industry: a data envelopment analysis (DEA) based approach. Journal of Cleaner Production, 142, 846-853.

Chin, T. A., Tat, H. H., \& Sulaiman, Z. (2015). Green supply chain management, environmental collaboration and sustainability performance. Procedia Cirp, 26, 695-699.

Choi, T. M. (2018). Incorporating social media observations and bounded rationality into fashion quick response supply chains in the big data era. Transportation Research Part E: Logistics and Transportation Review, 114, 386-397.

Dai, J., Cantor, D. E., \& Montabon, F. L. (2015). How environmental management competitive pressure affects a focal firm's environmental innovation activities: A green supply chain perspective. Journal of Business Logistics, 36(3), $242-259$.

Dong, Z., Tan, Y., Wang, L., Zheng, J., \& Hu, S. (2021). Green supply chain management and clean technology innovation: An empirical analysis of multinational enterprises in China. Journal of Cleaner Production, 310, 127377.

Dubey, R., Gunasekaran, A., Childe, S. J., Roubaud, D., Wamba, S. F., Giannakis, M., \& Foropon, C. (2019). Big data analytics and organizational culture as complements to swift trust and collaborative performance in the humanitarian supply chain. International Journal of Production Economics, 210, 120-136.

Eckstein, D., Goellner, M., Blome, C., \& Henke, M. (2015). The performance impact of supply chain agility and supply chain adaptability: the moderating effect of product complexity. International Journal of Production Research, 53(10), 30283046.

Edwin Cheng, T. C., Kamble, S. S., Belhadi, A., Ndubisi, N. O., Lai, K. H., \& Kharat, M. G. (2021). Linkages between big data analytics, circular economy, sustainable supply chain flexibility, and sustainable performance in manufacturing firms. International Journal of Production Research, 1-15. doi: 10.1080/00207543.2021.1906971.

Fernando, Y., Chidambaram, R. R., \& Wahyuni-TD, I. S. (2018). The impact of big data analytics and data security practices on service supply chain performance. Benchmarking: An International Journal, 25(9), 4009-4034.

Fornell, C., \& Larcker, D. F. (1981). Evaluating structural equation models with unobservable variables and measurement error. Journal of Marketing Research, 18(1), 39-50.

Fraj-Andrés, E., Martínez-Salinas, E., \& Matute-Vallejo, J. (2009). Factors affecting corporate environmental strategy in Spanish industrial firms. Business strategy and the Environment, 18(8), 500-514.

Frizzo-Barker, J., Chow-White, P. A., Mozafari, M., \& Ha, D. (2016). An empirical study of the rise of big data in business scholarship. International Journal of Information Management, 36(3), 403-413.

Gavronski, I., Klassen, R. D., Vachon, S., \& do Nascimento, L. F. M. (2011). A resource-based view of green supply management. Transportation Research Part E: Logistics and Transportation Review, 47(6), 872-885.

George, G., Haas, M.R. and Pentland, A. (2014). Big data and management. Academy of Management Journal, 57(2), 321326.

Govindan, K., Cheng, T.C.E., Mishra, N., \& Shukla, N. (2018). Big data analytics and application for logistics and supply chain management. Transportation Research Part E: Logistics and Transportation Review, 114, 343-349.

Green, K.W., Zelbst, P.J., Meacham, J., \& Bhadauria, V.S. (2012). Green supply chain management practices: impact on performance. Supply Chain Management, 17(3), 290-305.

Gunasekaran, A., Papadopoulos, T., Dubey, R., Wamba, S. F., Childe, S. J., Hazen, B., \& Akter, S. (2017). Big data and predictive analytics for supply chain and organizational performance. Journal of Business Research, 70, 308-317.

Habib, M., Bao, Y., Nabi, N., Dulal, M., Asha, A. A., \& Islam, M. (2021). Impact of strategic orientations on the implementation of green supply chain management practices and sustainable firm performance. Sustainability, 13(1), 340 . 
Hair, J. F., Ringle, C. M., \& Sarstedt, M. (2011). PLS-SEM: Indeed, a silver bullet. Journal of Marketing Theory and Practice, 19(2), 139-152.

Hall, J. K., Daneke, G. A., \& Lenox, M. J. (2010). Sustainable development and entrepreneurship: Past contributions and future directions. Journal of business venturing, 25(5), 439-448.

Hazen, B. T., Skipper, J. B., Ezell, J. D., \& Boone, C. A. (2016). Big data and predictive analytics for supply chain sustainability: A theory-driven research agenda. Computers \& Industrial Engineering, 101, 592-598.

Hsu, C.-C., Tan, K.-C. and Mohamad Zailani, S.H. (2016). Strategic orientations, sustainable supply chain initiatives, and reverse logistics: Empirical evidence from an emerging market. International Journal of Operations \& Production Management, 36(1), 86-110.

Huin, S. F., Luong, L. H. S., \& Abhary, K. (2003). Knowledge-based tool for planning of enterprise resources in ASEAN SMEs. Robotics and Computer-Integrated Manufacturing, 19(5), 409-414.

Jarrahi, M. H. (2018). Artificial intelligence and the future of work: Human-AI symbiosis in organizational decision making. Business Horizons, 61(4), 577-586.

Jeble, S., Dubey, R., Childe, S.J., Papadopoulos, T., Roubaud, D. and Prakash, A. (2018). Impact of big data and predictive analytics capability on supply chain sustainability. The International Journal of Logistics Management, 29(2), 513-538.

Jha, A. K., Agi, M. A., \& Ngai, E. W. (2020). A note on big data analytics capability development in supply chain. Decision Support Systems, 138, 1-9.

Joghee, S., Alzoubi, H. M., Alshurideh, M., \& Al Kurdi, B. (2021). The role of business intelligence systems on green supply chain management: Empirical analysis of FMCG in the UAE. In The International Conference on Artificial Intelligence and Computer Vision (pp. 539-552). Springer, Cham.

Kache, F., \& Seuring, S. (2017). Challenges and opportunities of digital information at the intersection of big data analytics and supply chain management. International Journal of Operations \& Production Management, 37(1), 10-36.

Kamble, S. S., \& Gunasekaran, A. (2020). Big data-driven supply chain performance measurement system: a review and framework for implementation. International Journal of Production Research, 58(1), 65-86.

Keszey, T. (2020). Environmental orientation, sustainable behaviour at the firm-market interface and performance. Journal of Cleaner Production, 243, 1-13.

Khan, M., Hussain, M., \& Saber, H. M. (2016). Information sharing in a sustainable supply chain. International Journal of Production Economics, 181, 208-214.

Kirchoff, J. F., Tate, W. L., \& Mollenkopf, D. A. (2016). The impact of strategic organizational orientations on green supply chain management and firm performance. International Journal of Physical Distribution \& Logistics Management.,46 (3), 269- 292.

Kock, N. (2014). Advanced mediating effects tests, multi-group analyses, and measurement model assessments in PLS-based SEM. International Journal of e-Collaboration (IJeC), 10(1), 1-13.

Krause, D. R., Vachon, S., \& Klassen, R. D. (2009). Special topic forum on sustainable supply chain management: introduction and reflections on the role of purchasing management. Journal of Supply Chain Management, 45(4), 18-25.

Kumar, A., Shankar, R., Choudhary, A., \& Thakur, L. S. (2016). A big data MapReduce framework for fault diagnosis in cloud-based manufacturing. International Journal of Production Research, 54(23), 7060-7073.

Lai, K. H., Wu, S. J., \& Wong, C. W. (2013). Did reverse logistics practices hit the triple bottom line of Chinese manufacturers?. International Journal of Production Economics, 146(1), 106-117.

Lamba, K., \& Singh, S. P. (2019). Dynamic supplier selection and lot-sizing problem considering carbon emissions in a big data environment. Technological Forecasting and Social Change, 144, 573-584.

Laosirihongthong, T., Adebanjo, D., \& Tan, K. C. (2013). Green supply chain management practices and performance. Industrial Management \& Data Systems, 113(8), 1088-1109.

Leonidou, L. C., Fotiadis, T. A., Christodoulides, P., Spyropoulou, S., \& Katsikeas, C. S. (2015). Environmentally friendly export business strategy: Its determinants and effects on competitive advantage and performance. International Business Review, 24(5), 798-811.

Li, B., Ch'ng, E., Chong, A. Y. L., \& Bao, H. (2016). Predicting online e-marketplace sales performances: A big data approach. Computers \& Industrial Engineering, 101, 565-571.

Li, D., \& Wang, X. (2017). Dynamic supply chain decisions based on networked sensor data: an application in the chilled food retail chain. International Journal of Production Research, 55(17), 5127-5141.

Li, L., Su, X., Wang, Y., Lin, Y., Li, Z., \& Li, Y. (2015). Robust causal dependence mining in big data network and its application to traffic flow predictions. Transportation Research Part C: Emerging Technologies, 58, 292-307.

Liu, B., \& De Giovanni, P. (2019). Green process innovation through Industry 4.0 technologies and supply chain coordination. Annals of Operations Research, 1-36.

Mageto, J. (2021). Big data analytics in sustainable supply chain management: A focus on manufacturing supply chains. Sustainability, 13(13), 2-22.

Mandal, S. (2018). An examination of the importance of big data analytics in supply chain agility development: A dynamic capability perspective. Management Research Review, 41(10),1201-1219.

Mandal, S. (2019). The influence of big data analytics management capabilities on supply chain preparedness, alertness and agility: An empirical investigation. Information Technology \& People, 32(2), 297-318.

Mangla, S. K., Kusi-Sarpong, S., Luthra, S., Bai, C., Jakhar, S. K., \& Khan, S. A. (2020). Operational excellence for improving sustainable supply chain performance. Resources, Conservation, and Recycling, 162, 105025. 
Mariadoss, B. J., Chi, T., Tansuhaj, P., \& Pomirleanu, N. (2016). Influences of firm orientations on sustainable supply chain management. Journal of Business Research, 69(9), 3406-3414.

Min, H. (2010). Artificial intelligence in supply chain management: theory and applications. International Journal of Logistics: Research and Applications, 13(1), 13-39.

Mubarik, M., Raja Mohd Rasi, R.Z., Mubarak, M.F., \& Ashraf, R. (2021). Impact of blockchain technology on green supply chain practices: evidence from emerging economy. Management of Environmental Quality, 32(5), 1023-1039.

Namagembe, S., Sridharan, R., \& Ryan, S. (2016). Green supply chain management practice adoption in Ugandan SME manufacturing firms: The role of enviropreneurial orientation. World Journal of Science, Technology and Sustainable Development, 13(3), 154-173.

Nguyen, T., Li, Z. H. O. U., Spiegler, V., Ieromonachou, P., \& Lin, Y. (2018). Big data analytics in supply chain management: A state-of-the-art literature review. Computers \& Operations Research, 98, 254-264.

Nunnally, J. C. (1994). Psychometric theory 3E. Tata McGraw-hill education.

Oláh, J., Aburumman, N., Popp, J., Khan, M. A., Haddad, H., \& Kitukutha, N. (2020). Impact of Industry 4.0 on environmental sustainability. Sustainability, 12(11), 4674.

Pan, S., Ballot, E., Huang, G.Q., \& Montreuil, B. (2017). Physical internet and interconnected logistics services: research and applications. International Journal of Production Research, 55, 2603-2609.

Papadopoulos, T., Gunasekaran, A., Dubey, R., Altay, N., Childe, S. J., \& Fosso-Wamba, S. (2017). The role of big data in explaining disaster resilience in supply chains for sustainability. Journal of Cleaner Production, 142, 1108-1118.

Peng, X. R., \& Wei, J. (2015). Stakeholders' environmental orientation and eco-innovation: The moderating role of top managers' environmental awareness. Studies in Science of Science, 33(7), 1109-1120.

Priya, M., \& Kumar, P.R. (2015). A novel intelligent approach for predicting atherosclerotic individuals from big data for healthcare. International Journal of Production Research, 53(24), 7517-7532.

Queiroz, M.M., \& Telles, R. (2018). Big data analytics in supply chain and logistics: an empirical approach. The International Journal of Logistics Management, 29(2), 767-783.

Ramanathan, U., Subramanian, N., \& Parrott, G. (2017). Role of social media in retail network operations and marketing to enhance customer satisfaction. International Journal of Operations \& Production Management, 37(1), 105-123.

Raut, R. D., Mangla, S. K., Narwane, V. S., Dora, M., \& Liu, M. (2021). Big data analytics as a mediator in lean, agile, resilient, and green (LARG) practices effects on sustainable supply chains. Transportation Research Part E: Logistics and Transportation Review, 145, 102170.

Riahi, Y., Saikouk, T., Gunasekaran, A., \& Badraoui, I. (2021). Artificial intelligence applications in supply chain: A descriptive bibliometric analysis and future research directions. Expert Systems with Applications, 173, 1-19.

Roßmann, B., Canzaniello, A., von der Gracht, H., \& Hartmann, E. (2018). The future and social impact of big data analytics in supply chain management: Results from a Delphi study. Technological Forecasting and Social Change, 130, $135-149$.

Schoenherr, T., \& Speier-Pero, C. (2015). Data science, predictive analytics, and big data in supply chain management: Current state and future potential. Journal of Business Logistics, 36(1), 120-132.

Shokouhyar, S., Seddigh, M.R., \& Panahifar, F. (2020). Impact of big data analytics capabilities on supply chain sustainability: A case study of Iran. World Journal of Science, Technology and Sustainable Development, 17(1), 33-57.

Silva, M.E., Alves, A.P.F., Dias, P., \& Nascimento, L.F.M. (2019). The role of orientation towards sustainability in supply chains: Insights from empirical experiences. Benchmarking: An International Journal, ahead-of-print No. ahead-ofprint. https://doi.org/10.1108/BIJ-07-2017-0184.

Singh, A., \& Teng, J. T. (2016). Enhancing supply chain outcomes through information technology and trust. Computers in human behavior, 54, 290-300.

Singh, S. K., \& El-Kassar, A. N. (2019). Role of big data analytics in developing sustainable capabilities. Journal of cleaner production, 213, 1264-1273.

Song, M. \& Wang, S. (2018). Market competition, green technology progress and comparative advantages in China. Management Decision, 56(1), 188-203.

Song, M., Peng, J., Wang, J., \& Dong, L. (2018). Better resource management: An improved resource and environmental efficiency evaluation approach that considers undesirable outputs. Resources, conservation and recycling, 128, 197-205.

Srinivasan, R., \& Swink, M. (2018). An investigation of visibility and flexibility as complements to supply chain analytics: An organizational information processing theory perspective. Production and Operations Management, 27(10), 18491867.

Tan, K. H., Zhan, Y., Ji, G., Ye, F., \& Chang, C. (2015). Harvesting big data to enhance supply chain innovation capabilities: An analytic infrastructure based on deduction graph. International Journal of Production Economics, 165, $223-233$.

Tiwari, S., Wee, H. M., \& Daryanto, Y. (2018). Big data analytics in supply chain management between 2010 and 2016 : Insights to industries. Computers \& Industrial Engineering, 115, 319-330.

Toorajipour, R., Sohrabpour, V., Nazarpour, A., Oghazi, P., \& Fischl, M. (2021). Artificial intelligence in supply chain management: A systematic literature review. Journal of Business Research, 122, 502-517.

Tseng, M. L., Lim, M., Wu, K. J., Zhou, L., \& Bui, D. T. D. (2018). A novel approach for enhancing green supply chain management using converged interval-valued triangular fuzzy numbers-grey relation analysis. Resources, Conservation and Recycling, 128, 122-133.

Waller, M. A., \& Fawcett, S. E. (2013). Data science, predictive analytics, and big data: A revolution that will transform supply chain design and management. Journal of Business Logistic, 34, 77-84. 
Wamba, S. F., Akter, S., Edwards, A., Chopin, G., \& Gnanzou, D. (2015). How 'big data' can make big impact: Findings from a systematic review and a longitudinal case study. International Journal of Production Economics, 165, 234-246.

Wamba, S. F., Dubey, R., Gunasekaran, A., \& Akter, S. (2020). The performance effects of big data analytics and supply chain ambidexterity: The moderating effect of environmental dynamism. International Journal of Production Economics, 222, 1-14.

Wang, C., Li, X., Zhou, X., Wang, A., \& Nedjah, N. (2016). Soft computing in big data intelligent transportation systems. Applied Soft Computing, 38, 1099-1108.

Wang, G., Gunasekaran, A., \& Ngai, E. W. (2018). Distribution network design with big data: model and analysis. Annals of Operations Research, 270(1), 539-551.

Wong, C.Y., Wong, C.W., \& Boon-itt, S., (2015). Integrating environmental management into supply chains: a systematic literature review and theoretical framework. International Journal of Physical Distribution \& Logistics Management, 45 $(1 / 2), 43-68$.

Wu, K. J., Liao, C. J., Tseng, M. L., Lim, M. K., Hu, J., \& Tan, K. (2017). Toward sustainability: using big data to explore the decisive attributes of supply chain risks and uncertainties. Journal of Cleaner Production, 142, 663-676.

Yasir, M., Majid, A., \& Qudratullah, H. (2020). Promoting environmental performance in manufacturing industry of developing countries through environmental orientation and green business strategies. Journal of Cleaner Production, 275, 1-12.

Yu, W., Wong, C. Y., Chavez, R., \& Jacobs, M. A. (2021). Integrating big data analytics into supply chain finance: The roles of information processing and data-driven culture. International Journal of Production Economics, 236, 1-13.

$\mathrm{Yu}, \mathrm{Y} .$, \& Huo, B. (2019). The impact of environmental orientation on supplier green management and financial performance: The moderating role of relational capital. Journal of cleaner production, 211, 628-639.

Zaid, A. A., Jaaron, A. A., \& Bon, A. T. (2018). The impact of green human resource management and green supply chain management practices on sustainable performance: An empirical study. Journal of cleaner production, 204, 965-979.

Zhang, H., \& Yang, F. (2016). On the drivers and performance outcomes of green practices adoption: An empirical study in China. Industrial Management \& Data Systems, 116(9), 2011-2034.

Zhang, X., Yu, Y., \& Zhang, N. (2021). Sustainable supply chain management under big data: a bibliometric analysis. Journal of Enterprise Information Management, 34(1), 427-445.

Zhang, Y., Ren, S., Liu, Y., \& Si, S. (2017). A big data analytics architecture for cleaner manufacturing and maintenance processes of complex products. Journal of cleaner production, 142, 626-641.

Zhao, R., Liu, Y., Zhang, N., \& Huang, T. (2017). An optimization model for green supply chain management by using a big data analytic approach. Journal of Cleaner Production, 142, 1085-1097.

Zhong, R. Y., Newman, S. T., Huang, G. Q., \& Lan, S. (2016). Big data for supply chain management in the service and manufacturing sectors: Challenges, opportunities, and future perspectives. Computers \& Industrial Engineering, 101, 572-591.

Zhong, R. Y., Xu, C., Chen, C., \& Huang, G. Q. (2017). Big data analytics for physical internet-based intelligent manufacturing shop floors. International journal of production research, 55(9), 2610-2621.

Zhou, K. Z., Li, J. J., Zhou, N., \& Su, C. (2008). Market orientation, job satisfaction, product quality, and firm performance: evidence from China. Strategic management journal, 29(9), 985-1000.

Zhu, Q., Sarkis, J., \& Lai, K. H. (2013). Institutional-based antecedents and performance outcomes of internal and external green supply chain management practices. Journal of Purchasing and Supply Management, 19(2), 106-117.

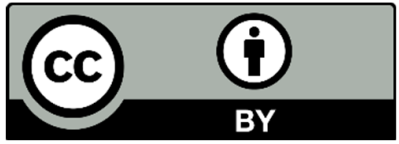

(C) 2022 by the authors; licensee Growing Science, Canada. This is an open access article distributed under the terms and conditions of the Creative Commons Attribution (CC-BY) license (http://creativecommons.org/licenses/by/4.0/). 